\title{
Protozoa stimulate the plant beneficial activity of rhizospheric pseudomonads
}

\author{
Simone Weidner $(\mathbb{D} \cdot$ Ellen Latz • Betina Agaras • \\ Claudio Valverde $\cdot$ Alexandre Jousset
}

Received: 19 April 2016/Accepted: 19 October 2016/Published online: 5 November 2016

(C) The Author(s) 2016. This article is published with open access at Springerlink.com

\begin{abstract}
Aims The functioning of plant-associated bacteria is strongly influenced by their interaction with other organisms. For instance, bacteria upregulate the production of secondary metabolites in presence of protozoa and we hypothesised that this interaction may contribute to plant health.
\end{abstract}

Responsible Editor: Sven Marhan.

Electronic supplementary material The online version of this article (doi:10.1007/s11104-016-3094-8) contains supplementary material, which is available to authorized users.

S. Weidner $\cdot$ E. Latz $\cdot$ A. Jousset

J. F. Blumenbach Institute of Zoology and Anthropology, Georg-August University Göttingen, Berliner Str. 28, 37073 Göttingen, Germany

S. Weidner $(\square) \cdot$ A. Jousset

Present Address: Institute of Environmental Biology, Utrecht University, Padualaan 8, 3584 CHUtrecht, The Netherlands e-mail: s.weidner@uu.nl

\section{E. Latz}

Present Address: German Centre for Integrative Biodiversity Research (iDiv) Halle-Jena-Leipzig, Deutscher Platz 5e, 04103 Leipzig, Germany

\section{E. Latz}

Present Address: Institute of Ecology, Friedrich Schiller University Jena, Dornburger-Str. 159, 07743 Jena, Germany

\section{B. Agaras $\cdot$ C. Valverde}

Laboratorio de Bioquímica, Microbiología e Interacciones Biológicas en el Suelo, Departamento de Ciencia y Tecnología, Universidad Nacional de Quilmes - CONICET, Roque Sáenz Peña 352, Bernal B1876BXD, Buenos Aires, Argentina
Methods Here, we tested if the effect of beneficial pseudomonads on wheat growth and health is modified by coinoculation with the bacterivorous amoeba Acanthamoeba castellanii. We assessed effects of this co-inoculation in absence and presence of the root pathogen Pythium ultimum.

Results In absence of amoebae, bacterial isolates had few beneficial effects and some isolates exacerbated growth inhibition by the pathogen (despite their reported beneficial effects in vitro). Effects on plant growth in absence and presence of the pathogen were negatively correlated. Co-inoculation with amoebae suppressed this relationship, leading to plant growth promotion in absence and reduction of deleterious effects in presence of the pathogen. The positive effect of amoebae in absence of the pathogen could be related to bacterial siderophore production in vitro.

Conclusions Our results illustrate the discrepancy between in vitro and in vivo effects of plant beneficial bacteria. Incorporation of other rhizospheric trophic components such as protists may be a key factor to influence the plant-beneficial potential of bacteria in vivo.

Keywords Protozoa $\cdot$ Rhizosphere $\cdot$ Pathogen inhibition · Plant growth promotion · Pseudomonas . Wheat

\section{Introduction}

Plant growth and health largely depend on their association with beneficial microbes that are able to stimulate growth by producing hormones or volatile compounds 
or by suppressing diseases (Berendsen et al. 2012). During the past decades, there has been a growing interest in applying bacterial strains with a certain plant beneficial activity to enhance crop productivity in a sustainable way (Lugtenberg and Kamilova 2009). Considerable efforts have been undertaken to characterize the traits underlying pathogen suppression and targeted screening procedures have been developed to isolate beneficial bacteria (Fravel 2005). Bacteria are typically screened and assessed in controlled environments. However, in natural settings bacteria are interacting with several organisms. As the physiology of beneficial microbes is strongly influenced by biotic interactions (Dubuis et al. 2007; Mazzola et al. 2009; Jousset and Bonkowski 2010; Garbeva et al. 2011), we tested whether integrating other organisms could alter the bacterial effect on plant growth and pathogen inhibition.

Here, we focused on the impact of protozoa on the activity of plant growth promoting rhizobacteria. Protozoa are a key component of soil ecosystems (Ekelund and Rønn 1994). Protozoa can affect plant health by mineralizing nutrients and altering the structure and activity of root-associated communities (Bonkowski 2004). Predation by protozoa may for instance promote the production of plant growth hormones (Krome et al. 2010) or enhance the survival of beneficial microbes suppressing pathogens (Jousset et al. 2008; Müller et al. 2013). Further, protozoa can stimulate the production of compounds linked to disease suppression, such as antibiotics (Mazzola et al. 2009; Jousset et al. 2010) or siderophores (Levrat et al. 1989). Accordingly, we expected that coinoculating beneficial bacteria with bacterivorous protozoa may translate to an improved plant growth and health.

We assessed the ability of nine beneficial Pseudomonas isolates to promote the growth of wheat and reduce growth inhibition of wheat caused by the plant pathogen Pythium ultimum. We set up a microcosm experiment with wheat seedlings inoculated with bacteria alone or together with the amoeba Acanthamoeba castellanii and determined shoot length, shoot weight and root weight as estimators for plant growth and health.

\section{Material and methods}

Amoeba and bacterial isolates

Acanthamoeba castellanii was isolated from a German woodland (Bonkowski and Brandt 2002) and kept axenic on protease peptone yeast extract (2\% w/v peptone, $0.25 \%$ $w / v$ yeast-extract). Prior to experiments, an active culture was collected by gentle centrifugation $(150 \times g)$, washed in $1 / 4$ strength Hoagland's mineral solution (Hoagland and Arnon 1950) and adjusted to a density of 120,000 individuals $/ \mathrm{mL}$. Nine pseudomonad isolates were chosen from a previously characterized collection retrieved from agricultural fields, of which eight isolates are described in Agaras et al. (2015). The ninth isolate (SPSA5) was characterized with the same methods as being a carrier of the phlD and prnD gene (encoding for DAPG and pyrrolnitrin), while being deficient in producing phenazine, $\mathrm{HCN}$, exoprotease and phospholipase (also see Table 1). The isolates were chosen to cover a gradient of in vitro antagonistic activity against Pythium ultimum strain $67-1$ in dual culture assays. Briefly, bacterial suspensions $\left(\mathrm{OD}_{600}=1.0,10 \mu \mathrm{L}\right)$ were spotted on the edge of malt agar plates and a mycelial plug $\left(1 \mathrm{~cm}^{2}\right)$ of $P$. ultimum was deposited in the centre of the plates, at approximately $3-4 \mathrm{~cm}$ from the bacterial spots (Ongena et al. 1999). Plates were incubated at room temperature and inhibition zones were measured after 5 days. The antagonistic activity of each isolate was ranked according to the extent of the inhibition zone (distance in $\mathrm{mm}$ from the border of the bacterial spot to the oomycete mycelium), as follows: strong (> $3 \mathrm{~mm}$ : RBAN4, SVBP3, SVBP6, SVBP8), moderate (1-3 mm: RBBP4, RPBP2, SMMP3), weak (< 1 mm: SPSA5, SVMP4; also see Table 1). For the growth experiment, isolates were grown over night in lysogeny broth at $28^{\circ} \mathrm{C}$, centrifuged $(10,000 \times g, 2 \mathrm{~min})$ and washed in sodium chloride $(0.85 \% w / v)$, resuspended in $1 / 4$ strength Hoagland's mineral solution and adjusted to an $\mathrm{OD}_{600}$ of 1 .

Seed surface sterilization and seedling pre growth

Wheat seeds (Triticum aestivum var. Baguette 19) were surface sterilized by soaking in $70 \%$ ethanol for $2 \mathrm{~min}$ followed by treatment with diluted commercial bleach $(0.6 \% \mathrm{v} / \mathrm{v}$ sodium hypochlorite) for $10 \mathrm{~min}$. After six washes with sterilized distilled water, surfacedisinfected seeds were deposited onto water agar plates $(1.5 \% \mathrm{w} / \mathrm{v})$ and stored overnight in a cold room $\left(4{ }^{\circ} \mathrm{C}\right)$, after which seedlings were germinated and pre-grown for $72 \mathrm{~h}$ at $20^{\circ} \mathrm{C}$.

\section{Experimental setup}

Seedlings were gently transferred to $110 \mathrm{~cm}^{3}$-pots filled with $15 \mathrm{~g}$ of autoclaved vermiculite and watered with 
$30 \mathrm{~mL}$ of $1 / 4$ strength Hoagland's mineral solution (1 seedling per pot). When appropriate, the substrate was artificially infested with the pathogenic oomycete Pythium ultimum strain $67-1$ by adding $15 \mathrm{~g}$ of a seven-day-old millet-seed inoculum of the pathogen per $\mathrm{kg}$ of substrate. Seedlings were inoculated with $20 \mu \mathrm{L}$ of the bacterial suspension and $100 \mu \mathrm{L}$ of the amoebae suspension according to the treatment. Controls received the corresponding amount of sterile $1 / 4$ strength Hoagland's mineral solution. For each treatment and bacterial isolate six pots were set up (for experimental design, see supplementary material 1). Pots were incubated in a greenhouse for eight days with minimum and maximum average temperatures of 20 and $28{ }^{\circ} \mathrm{C}$, a relative humidity ranging between 45 and $90 \%$ and a photoperiod of $16 \mathrm{~h}$ (Incandescent lamps (400 W, Osram, Brazil). Pots were randomized and seedling height was recorded daily.

In this study we focused on early plant growth. Since P. ultimum is a pathogen targeting early seedling development, it is important to look at possible interaction effects at this early stage, since it will affect later plant development (Mellano et al. 1970).

At the end of the experiment, plants were destructively harvested. Shoot length and fresh weight, and root dry weight were recorded separately for each plant and used as a measure for plant growth/health.

\section{Statistical analyses}

We used a generalized linear model (GLM) to investigate the effect of bacteria (factor, 9 levels), amoebae (factor, 2 levels) and Pythium ultimum (factor, 2 levels) on shoot fresh weight and length and root dry weight. For this analysis, non-bacterized samples were excluded.

In a second step, we defined the effect of each bacterium as the difference in the measured parameter between the bacterized treatment and the nonbacterized control. Therefore, we normalized the measured values for each bacterium by subtracting the average value of the non-bacterized control. We termed the effect of the bacteria in the pathogen-free treatment "plant growth promotion" and took the ability of the bacteria to decrease the plant growth inhibition caused by the pathogen as a proxy for effects on "pathogen inhibition" and plant health.
We assessed potential trade-offs between plant growth promotion and pathogen inhibition in presence and absence of amoebae using linear models with pairwise comparison of means. A significant negative correlation between plant growth promotion and pathogen inhibition indicates a trade-off between the two activities; a significant positive correlation between amoebae and plant growth promotion indicates that amoebae alleviate this trade-off.

In order to link the observed patterns to particular bacterial traits such as the production of antibiotics, we compared the effect of the bacterial isolates in the four absence/presence treatments of amoebae and P. ultimum to a trait matrix established in a previous experiment. This trait matrix covers the presence of genes coding for secondary metabolites such as hydrogen cyanide $(\mathrm{HCN})$, as well as in vitro semi-quantitative measurements, amongst others siderophore production (see Table 1 and Agaras et al. (2015)). For each trait we set up a separate GLM of the means with bacterial effects on plant growth as response variable and target trait as predictor.

Statistical analyses were performed using R 3.0.3 (R Core Team 2014) with the package car for ANOVA error type III analyses (Fox and Weisberg 2010).

\section{Results}

Both above- and belowground parts of the plants at the end of the experiment were affected by the different treatments with shoot fresh weight ranging from 0.05 to $0.21 \mathrm{~g}$ (for results of single isolates and non-bacterized control see supplementary material 2). Pythium ultimum and the bacterial isolates interactively affected root dry weight of the plants (see Table 2). Aboveground, there was a strong interactive effect between $P$. ultimum, bacterial isolates and amoebae, which was visible both for shoot fresh weight and length (see Table 2). In addition, analyses of shoot length measurements over time revealed that significant interactive effects already appeared four days after inoculation and were most pronounced after six days (see supplementary material 3).

These multiple interactive effects call for a further step in order to assess whether general patterns can be found. We therefore investigated the relationship between pathogen inhibition (P. ultimum present) and 
Table 1 Antagonism potential against Pythium ultimum, relative siderophore production, hydrogen cyanide production and taxonomic identification of the 9 Pseudomonas isolates used in this study.

\begin{tabular}{|c|c|c|c|c|c|}
\hline Bacterial isolate & $\begin{array}{l}\text { Pythium } \\
\text { inhibition }\end{array}$ & $\begin{array}{l}\text { Siderophore Relative } \\
\text { production }\end{array}$ & $\begin{array}{l}\text { HCN qualitative } \\
\text { production }\end{array}$ & $\begin{array}{l}\text { Pseudomonas } \\
\text { complex }\end{array}$ & $\begin{array}{l}\text { Reference } \\
\text { or Source }\end{array}$ \\
\hline RBAN4 & $>3 \mathrm{~mm}$ & $116.7 \pm 7.2$ & 1 & P. asplenii & Agaras et al. 2015 \\
\hline SVBP3 & $>3 \mathrm{~mm}$ & $57.1 \pm 12.4$ & 1 & P. chlororaphis & Agaras et al. 2015 \\
\hline SVBP6 & $>3 \mathrm{~mm}$ & $145.8 \pm 7.2$ & 1 & P. putida & Agaras et al. 2015 \\
\hline SVBP8 & $>3 \mathrm{~mm}$ & $70.8 \pm 7.2$ & 1 & P. chlororaphis & Agaras et al. 2015 \\
\hline RBBP4 & $1-3 \mathrm{~mm}$ & 0 & 1 & P. fluorescens & Agaras et al. 2015 \\
\hline RPBP2 & $1-3 \mathrm{~mm}$ & $104.2 \pm 7.2$ & 0 & P. asplenii & Agaras et al. 2015 \\
\hline SMMP3 & $1-3 \mathrm{~mm}$ & $58.3 \pm 7.2$ & 1 & P. chlororaphis & Agaras et al. 2015 \\
\hline SPSA5 & $<1 \mathrm{~mm}$ & $120.8 \pm 7.2$ & 0 & P. protegens & This study \\
\hline SVMP4 & $<1 \mathrm{~mm}$ & $30.4 \pm 6.4$ & 1 & P. putida & Agaras et al. 2015 \\
\hline
\end{tabular}

For details on measurement of siderophore and HCN production, see Agaras et al. (2015)

plant growth promotion (P. ultimum absent). We hereby focused on the aboveground part of the plants. To our surprise, in absence of amoebae most isolates had no or a net negative effect on plant growth (Fig. 1). In addition, we observed a clear trade-off between effects of bacteria on plant growth depending on presence or absence of the pathogen (Fig. 1): Bacteria inhibiting plant growth in absence of the pathogen showed no or a positive net effect in presence of the pathogen, while bacteria showing no effect alone even strengthened the effect of the pathogen $\left(\mathrm{F}_{1,7}=25.93\right.$, $P<0.001$, Fig. 1). The same trend can be seen for shoot length, albeit only as a tendency (see supplementary material 4). In contrast, this trade-off was no longer apparent in presence of amoeba, showing positive net growth effects in absence of the pathogen and alleviation of the negative net effects some bacteria had in presence of the pathogen $\left(\mathrm{F}_{1,7}=0.329, P=0.584\right.$, Fig. 1$)$. Further, we could see clear-cut shifts in the effects of some single isolates. For instance, co-inoculation with amoebae stimulated a plant growth promotion effect of RPBP2 and RBAN4 without changing their effect in presence of the pathogen, whilst it negated the negative effect of SMMP3 in presence of the pathogen without changing the isolates' effect in absence of the pathogen (see Fig. 1 and supplementary material 2).

We didn't find any interaction effect between presence of pathogen and presence of amoebae in the treatments without addition of bacteria (for shoot length: $P=0.366$; for shoot fresh weight: $P=0.719$; also see supplementary material 2, panels (s) and (t)).

We then related the results to the trait matrix and found that production of siderophores in vitro

Table 2 Summary of the three-way ANOVA (error type III) investigating the effect of inoculation of wheat plants with amoebae, Pythium ultimum and nine different antifungal pseudomonads on shoot length and fresh weight after eight days

\begin{tabular}{|c|c|c|c|c|c|c|c|}
\hline & \multirow[b]{2}{*}{$d . f}$. & \multicolumn{2}{|c|}{ Shoot length } & \multicolumn{2}{|c|}{ Shoot fresh weight } & \multicolumn{2}{|c|}{ Roots dry weight } \\
\hline & & $\mathrm{F}$ & $p$ & $\mathrm{~F}$ & $p$ & $\mathrm{~F}$ & $p$ \\
\hline Amoebae (AM) & 1 & 7.86 & 0.005 & 5.650 & 0.019 & 0.02 & 0.887 \\
\hline Pythium (PY) & 1 & 0.030 & 0.863 & 1.845 & 0.176 & 4.555 & 0.034 \\
\hline Bacterial Isolate (BI) & 8 & 0.252 & 0.980 & 1.239 & 0.279 & 3.304 & 0.002 \\
\hline $\mathrm{AM} \times \mathrm{PY}$ & 1 & 10.353 & 0.002 & 4.670 & 0.032 & 1.012 & 0.316 \\
\hline $\mathrm{AM} \times \mathrm{BI}$ & 8 & 0.952 & 0.475 & 2.405 & 0.017 & 1.746 & 0.091 \\
\hline BI x PY & 8 & 1.985 & 0.051 & 2.703 & 0.008 & 2.232 & $\mathbf{0 . 0 2 7}$ \\
\hline AM x PY x BI & 8 & 2.464 & 0.0148 & 2.867 & 0.005 & 1.522 & 0.152 \\
\hline
\end{tabular}

Significant effects are highlighted in bold, tendencies are highlighted in italic 
Fig. 1 Relationships between plant growth promotion of the nine bacterial isolates in absence of Pythium ultimum and effect on growth inhibition in presence P. ultimum. Each point corresponds to the average shoot fresh weight of a plant inoculated with one given strain minus the mean shoot fresh weight of the control treatment without bacteria. Blue points: bacteria alone, light red points: bacteria plus Acanthamoeba castellanii. Bars give the standard error

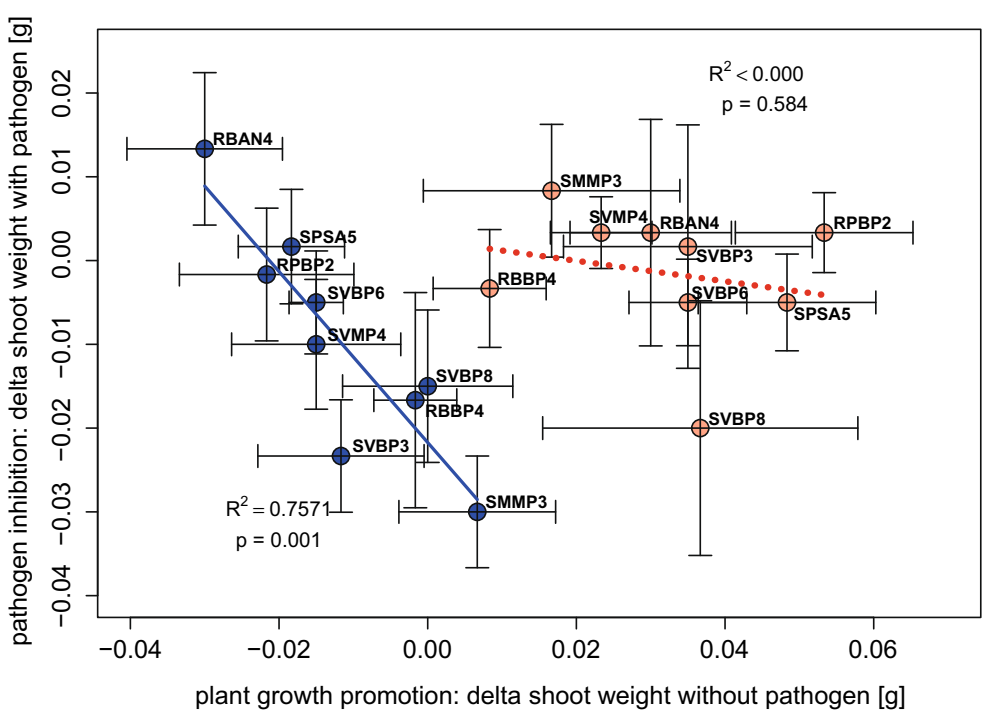

(continuous variable) correlated with an increased shoot fresh weight when isolates were co-inoculated with protozoa $\left(F_{1,7}=7.216, p=0.031\right.$, Fig. 2$)$. In contrast, addition of bacteria producing $\mathrm{HCN}$ resulted in a smaller shoot weight when they were co-inoculated with amoebae $\left(\mathrm{F}_{1,7}=9.143, p=0.019\right)$.

\section{Discussion}

Application of plant-beneficial bacteria bears a great potential to improve plant growth and to contribute to a low input, high yield agriculture. However, in order to use bacteria more efficiently we need to understand how their interactions with other organisms shape their activity. In the present study we show that coinoculation with protozoa can stimulate the plantbeneficial potential of bacteria. The consequence of root infections by Pythium ultimum could clearly be seen in the root dry weight of inoculated plants (see Table 2). On the other hand, the presence of amoebae did not affect root dry weight, but it did affect the aboveground part of the plants. When inoculated alone, most bacterial isolates had no or negative effects on plant growth. In addition we observed a trade-off: While some bacterial isolates had no effects on plant growth alone and even strengthened the effect of the pathogen, other bacterial isolates negatively affected plant growth alone but showed no or a positive net effect in the presence of the pathogen. This may be due to the genetic
Fig. 2 Relationship between the relative siderophore production in vitro and relative (delta) shoot fresh weight of plants inoculated with both the respective isolate plus Acanthamoeba castellanii. Each point corresponds to the average shoot fresh weight of plants inoculated with one given strain minus the mean shoot fresh weight of the control treatment without bacteria. Values for relative siderophore production of isolates are taken from Agaras et al. (2015). Bars give standard error

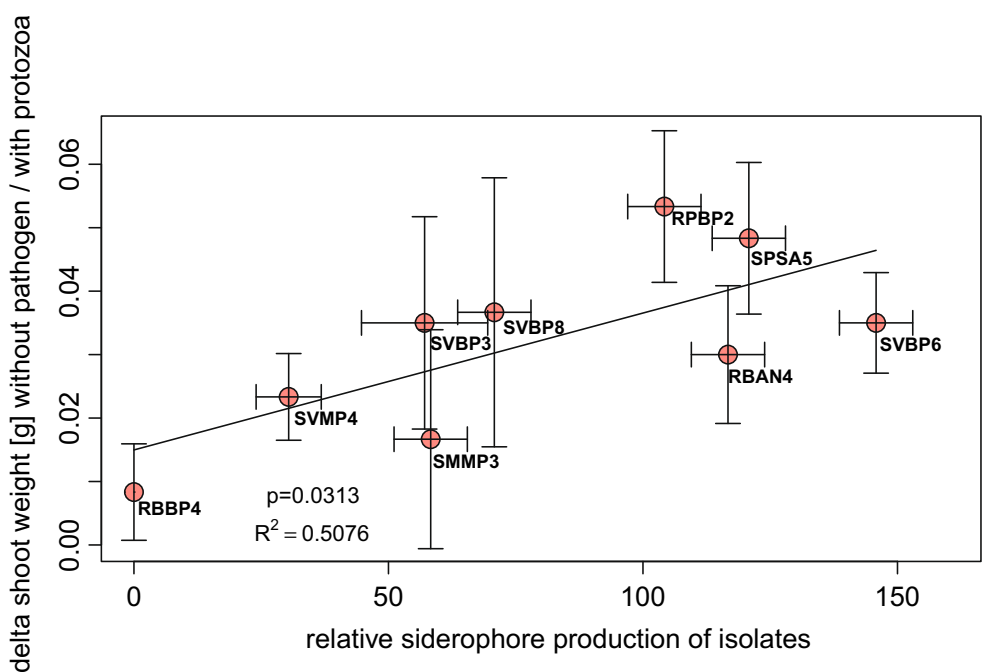


background of the bacteria: Using a multivariate traitbased approach, Agaras and colleagues showed that plant beneficial pseudomonads isolated from agricultural soils cluster into two different groups, with either traits linked to plant-growth promoting activity, for instance by producing hormones, or to disease suppression, such as via antibiotics production (Agaras et al. 2015). In addition, metabolites involved in pathogen suppression, e.g. 2, 4-DAPG and phenazines, can interfere with plant growth (Brazelton et al. 2008; Ortiz-Castro et al. 2013), suggesting that it may be difficult to merge plant growth promoting and/or disease suppressive capacities in one bacterial isolate. The fact that bacterial isolates bearing plant growth promoting and disease suppressive traits demonstrated no or even negative plant growth effects in this study when inoculated alone (in absence of amoebae and P. ultimum), strengthens the necessity of investigating further interactions of the bacteria with other organisms in the rhizosphere.

Co-inoculation of protozoa suppressed this trade-off, by enhancing the effect of bacteria on plant growth in the absence of the pathogen and alleviating the negative effect of some bacteria in the presence of the pathogen. Although the tested system did not allow for digging into underlying mechanisms, we propose a couple of possibilities. First, protozoa may have changed the nutritional status of the bacteria. Protozoa speed up nutrient cycling, making bacteria physiologically more active (Bonkowski 2004). Further, bacteria can sense the presence of protozoa and respond by upregulating the production of secondary metabolites such as 2, 4 DAPG or cyclic lipopeptides (Mazzola et al. 2009; Jousset and Bonkowski 2010). This enhanced activity may have influenced the ability of the bacteria to inhibit the pathogen. Second, the presence of protozoa resulted in increased plant growth in the absence of the pathogen. We speculate that this effect may be linked to different mechanisms. For instance, predation by protozoa may release amino-acids such as tryptophan, which in turn may stimulate auxin production (Krome et al. 2010), a phytohormone stimulating root growth. In addition, siderophore production in vitro correlated with plant growth promotion by the different bacteria, but only when protozoa were co-inoculated. Siderophores are a typical plant-growth promoting agent, helping plants to better access soil iron (Sharma et al. 2003). Protozoa can enhance siderophore production in bacteria (Levrat et al. 1989) and we propose that this enhanced trait expression may have contributed to plant growth.
In contrast, we found here that cyanide-producing bacteria reduced shoot growth in presence of protozoa. Several compounds linked to disease suppression can also inhibit plant growth. Cyanide is an important factor controlling a range of pathogens, but can at the same time show phytotoxic effects at high dose (Blom et al. 2011). This effect of cyanide in the presence of protozoa is reminiscent of past observations showing that protozoa increase cyanide production in pseudomonads (Jousset et al. 2010). Thus, it suggests that the direction of plant growth effects depends on which microbial traits are triggered by protozoa under the assessed conditions.

Although our statistical analysis didn't give indications for direct effects of the protozoa on the pathogen or vice versa, further studies are on the way to clarify if direct interactions, e.g. via feeding of the protozoa on the zoospores, might have occurred or might occur under specific circumstances.

We conclude that interactions between plant beneficial bacteria and protozoa may be an important driver of their effect on plant growth in natural soil. Native protozoa should thus be considered when applying beneficial microbes. Further, co-inoculation of protozoa with the beneficial bacteria may be an efficient way to increase plant beneficial activity of bacterial inoculants.

Acknowledgments This work was supported by grants PUNQ 1411/15 (National University of Quilmes, Argentina), JO 935/2-1 (German Research Foundation (DFG), Germany), FZT 118 (German Research Foundation (DFG), Germany), 01DN13009 (Federal Ministry of Education and Research (BMBF), Germany), Green Call project no. 870.15.050 (Netherlands Organisation for Scientific Research (NWO), the Netherlands), PIP $201101 n^{\circ} 00031$ (National Scientific and Technical Research Council (CONICET), Argentina) and AL-12-14 (Ministry of Science, Technology and Productive Innovation, Argentina). Claudio Valverde and Betina Agaras are members of CONICET.

\section{Compliance with ethical standards}

Conflict of interest The authors declare that they have no conflict of interest.

Open Access This article is distributed under the terms of the Creative Commons Attribution 4.0 International License (http://creativecommons.org/licenses/by/4.0/), which permits unrestricted use, distribution, and reproduction in any medium, provided you give appropriate credit to the original author(s) and the source, provide a link to the Creative Commons license, and indicate if changes were made. 


\section{References}

Agaras BC, Scandiani M, Luque A et al (2015) Quantification of the potential biocontrol and direct plant growth promotion abilities based on multiple biological traits distinguish different groups of Pseudomonas spp. isolates. Biol Control 90: 173-186. doi:10.1016/j.biocontrol.2015.07.003

Berendsen RL, Pieterse CMJ, Bakker PAHM (2012) The rhizosphere microbiome and plant health. Trends Plant Sci 17: 478-486. doi:10.1016/j.tplants.2012.04.001

Blom D, Fabbri C, Eberl L, Weisskopf L (2011) Volatile-mediated killing of Arabidopsis thaliana by bacteria is mainly due to hydrogen cyanide. Appl Environ Microbiol 77:1000-1008. doi:10.1128/AEM.01968-10

Bonkowski M (2004) Protozoa and plant growth: the microbial loop in soil revisited. New Phytol 162:617-631. doi:10.1111 j.1469-8137.2004.01066.x

Bonkowski M, Brandt F (2002) Do soil protozoa enhance plant growth by hormonal effects? Soil Biol Biochem 34:17091715. doi:10.1016/S0038-0717(02)00157-8

Brazelton JN, Pfeufer EE, Sweat TA et al (2008) 2,4diacetylphloroglucinol alters plant root development. Mol Plant-Microbe Interact 21:1349-1358. doi:10.1094/MPMI21-10-1349

Dubuis C, Keel C, Haas D (2007) Dialogues of root-colonizing biocontrol pseudomonads. Eur J Plant Pathol 119:311-328. doi:10.1007/s10658-007-9157-1

Ekelund F, Rønn R (1994) Notes on protozoa in agricultural soil with emphasis on heterotrophic flagellates and naked amoebae and their ecology. FEMS Microbiol Rev 15:321-353. doi:10.1111/j.1574-6976.1994.tb00144.x

Fox J, Weisberg S (2010) An R companion to applied regression. SAGE

Fravel DR (2005) Commercialization and implementation of biocontrol. Annu Rev Phytopathol 43:337-359. doi:10.1146 /annurev.phyto.43.032904.092924

Garbeva P, Silby MW, Raaijmakers JM et al (2011) Transcriptional and antagonistic responses of Pseudomonas fluorescens Pf0-1 to phylogenetically different bacterial competitors. ISME J 5:973-985. doi:10.1038/ismej.2010.196

Hoagland DR, Arnon DI (1950) The water-culture method for growing plants without soil. Circ Calif Agric Exp Stn 347:32 p.

Jousset A, Bonkowski M (2010) The model predator Acanthamoeba castellanii induces the production of 2,4, DAPG by the biocontrol strain Pseudomonas fluorescens Q2-87. Soil Biol Biochem 42:1647-1649. doi:10.1016/j. soilbio.2010.05.018

Jousset A, Scheu S, Bonkowski M (2008) Secondary metabolite production facilitates establishment of rhizobacteria by reducing both protozoan predation and the competitive effects of indigenous bacteria. Funct Ecol 22:714-719. doi:10.1111/j.1365-2435.2008.01411.x

Jousset A, Rochat L, Scheu S et al (2010) Predator-prey chemical warfare determines the expression of biocontrol genes by rhizosphere-associated Pseudomonas fluorescens. Appl Environ Microbiol 76:5263-5268. doi:10.1128/AEM.02941-09

Krome K, Rosenberg K, Dickler C et al (2010) Soil bacteria and protozoa affect root branching via effects on the auxin and cytokinin balance in plants. Plant Soil 328:191-201. doi:10.1007/s11104-009-0101-3

Levrat P, Pussard M, Alabouvette C (1989) Action D'Acanthamoeba castellanii (Protozoa, Amoebida) sur la production de sidérophores par la bactérie Pseudomonas putida. Comptes Rendus Académie Sci Sér 3 Sci Vie 308: 161-164.

Lugtenberg B, Kamilova F (2009) Plant-growth-promoting rhizobacteria. Annu Rev Microbiol 63:541-556. doi:10.1146/annurev.micro.62.081307.162918

Mazzola M, de Bruijn I, Cohen MF, Raaijmakers JM (2009) Protozoan-induced regulation of cyclic lipopeptide biosynthesis is an effective predation defense mechanism for Pseudomonas fluorescens. Appl Environ Microbiol 75: 6804-6811. doi:10.1128/AEM.01272-09

Mellano H, Munnecke D, Endo R (1970) Relationship of seedling age to development of Pythium ultimum on roots. Phytopathology 60:935-.

Müller MS, Scheu S, Jousset A (2013) Protozoa drive the dynamics of culturable biocontrol bacterial communities. PLoS One 8:e66200. doi:10.1371/journal.pone.0066200

Ongena M, Daayf F, Jacques P et al (1999) Protection of cucumber against Pythium root rot by fluorescent pseudomonads: predominant role of induced resistance over siderophores and antibiosis. Plant Pathol 48:66-76. doi:10.1046/j.13653059.1999.00315.x

Ortiz-Castro R, Pelagio-Flores R, Méndez-Bravo A et al (2013) Pyocyanin, a virulence factor produced by Pseudomonas aeruginosa, alters root development through reactive oxygen species and ethylene signaling in Arabidopsis. Mol Plant-Microbe Interact 27:364-378. doi:10.1094/MPMI-08-13-0219-R

R Core Team (2014) R: a language and environment for statistical computing. R Foundation for Statistical Computing, Vienna, Austria

Sharma A, Johri BN, Sharma AK, Glick BR (2003) Plant growthpromoting bacterium Pseudomonas sp. strain GRP3 influences iron acquisition in mung bean (Vigna radiata $\mathrm{L}$. Wilzeck). Soil Biol Biochem 35:887-894. doi:10.1016 /S0038-0717(03)00119-6 